\title{
Smiling again after fifteen years of torture
}

\section{Charline Musaniwabo}

I am Charline Musaniwabo. I was born in 1976. My parents were farmers. I lived with them up to April 1994.

My life completely changed during the genocide, having been married forcibly and losing many of my family members. I was born into a family of nine children, four boys and five girls. Five siblings and both my parents died during the genocide. Four of us escaped. I did not get a chance to marry a man I loved, because I was taken by force in 1994 by a neighbour who raped and married me. I live with the three children I conceived with this man.

In 1992, genocide took place in Bugesera. In Murama and Kanzenze, people were killed. Hutus burnt Tutsi houses, but in our area nobody was killed. They only ate cows belonging to Tutsi people. Despite all of this, when the 1994 genocide started I still did not think that as many people would be killed as were indeed killed.

The genocide mayhem spread everywhere. When it began, my whole family left our house in order to look for a place to hide. I took my things and gave them to a friend of mine who was a Hutu girl so that she could keep them for me. After giving her my stuff, my sister-in-law and I went to hide at the home of our Hutu neighbour, who was a Pentecostal Church member. We stayed in his house for two days and on the third day we went to a nearby primary school, thinking that it would be a safer place. We spent two days in the school while the war violence increased. Men who were with us advised us to look for another place to hide because things were getting worse. Since we had nowhere else to go, we took refuge in a nearby swamp where, after four days, a club of Interahamwe found us hiding there.

One of those Interahamwe took me to his parents' house. He lied to me, saying that he was going to hide me. I spent the night in that house and started to trust him. After two days, however, he began to rape me. He told me that the genocide would continue and that I should become his wife. I refused sexual intercourse with him. I continued begging him to leave me alone, wanting to go back to the swamp. He terrorized me and told me that if I went back he would kill me. I was afraid. The situation outside was bad. I stayed with him because I had no choice. It was very hard to be raped and survive. No one supported me during the genocide. A man who should have helped me violated me instead. Many women were killed by their 'husbands' who raped them once they heard that the Inkotanyi were around, but we continued to live together at his place. I did not know him before because he was new in our neighbourhood.

The most traumatic experience related to the genocide was the rape. During the fifteen years after the genocide that I lived with this rapist, he tortured me. I could not speak with him about the way my family was killed or about the death of my siblings. At each period of commemoration, I went to bed and cried until the end of the period. What was most painful is that when he found me crying he liked to tell me, "It is of no importance that Tutsis were killed." 
Throughout my whole life with him I was always afraid. I never felt happiness. Since the day he took me from the swamp, I expected him to kill me. During the memorial period he insulted me, as if I had no right to cry.

It was not only him who discriminated against me. Everyone stigmatized me. Survivors could not talk to me. Hutus used to tell my perpetrator that it was his own fault that he lived in poverty, because he married a Tutsi woman who was not able to cultivate.

Nobody else was allowed in our home. That man hated all survivors. He used to say that they were all witches, and that all male survivors were my husbands. He used to pour all of the local beer I was intending to sell all over my body, thus wasting it. He also hates his children, because they look like me. All of my siblings hated me too. They could not come to my house. They discriminated against me instead. They were saying that I should leave this husband. Even though my sister told me to leave the rapist, I did not do it because I did not want to become a burden to anyone. On the other side, the family of this man also disliked me. As people stigmatized me, I was afraid of attending the survivors meetings because I also stigmatized myself. I felt as though I was in jail.

In 2009, this man started to behave even worse to me because I refused to sell a plot of land which had belonged to my parents. After this he said that, because we were very poor, he was going to marry a rich woman. The situation was aggravated by the death of one of our four children. In 2010 the child fell sick and was hospitalized. The man refused to pay the hospital fees. During the week I spent in the hospital, he did not come to visit me. After the death of my child, it was my sister who paid the hospital. Coming home, when it was time to bury the dead body of my son, his father did not want him to be buried in what he considered to be 'his' plot of land, while I owned half of it. $\mathrm{He}$ wanted to sell the whole plot in order to marry a rich woman. He told me that if I buried the child in his land, he would kill me just like another man from our neighbourhood had killed his wife. After I refused to bury the child in the ruins of my parents' house, I separated from this man because he was making our lives too stressful. My sister started to rent a house for me.

Throughout the whole period that I spent with this man, I suffered from psychological problems. I was living in isolation, always crying. A time came when I felt hate towards myself and towards everything else. I stopped going to church. I was depressed, living in fear and grief. I always had headaches and nightmares. I experienced ihahamuka, especially during the commemoration period. I was always falling ill in April, feeling like a brainless woman. I only went to commemorate once, in 2006, when we buried the remains of my brother whom I loved so much, and who died at the last minute of the genocide.

Even though I was suffering, I did not go to the hospital. I was always at home. I regained my wits after my separation from that man and after I started to join other women and collaborate with them. I was no longer in that man's prison. The separation somehow reduced the sadness and other problems I had. After separating from this man, I had my rights back, the ones I had been deprived of for fifteen years. Before, I was not even allowed to benefit from survivor support. I was told that I was not a survivor. Now separated, I am supported like other vulnerable survivors. I did not benefit from any counselling because I was not informed about which organizations provided counselling. 
Through the grace of God, one woman who was my neighbour came to me. This woman, who later became a friend of mine, had completed fifteen weeks of sociotherapy. Because she had stayed near me while I was going through difficult times, I became open and shared my problems with her. She would advise me when I had problems. She became like my mother. I told her everything because she listened to me. After speaking about all my sorrows my heart was released. The deep thoughts I had about my life reduced. Before I spoke to her, I was always thinking about the rape I was experiencing and living in loneliness.

In 2011, after I separated with the rapist, I was invited by another female neighbour to join sociotherapy. Even though I accepted her invitation, I could not see any interest in going to the meeting place in Nyamata every week. During the first four weeks I was wondering why I would go to Nyamata just to cry. Once, one of our facilitators explained to us the importance of crying. I learned that when you cry, you feel your heart being released. After understanding the significance of crying, I continued to participate. After four weeks I started to like sociotherapy.

Before joining sociotherapy, I was always thinking about myself. I was always angry, and I was full of grudges. I also felt that I wanted to live alone. Surprisingly, while I was following sociotherapy, I felt changes in my whole body. The anger, thinking deeply about myself, all these symptoms disappeared. The loneliness has gone. I am no longer crying whenever, as I was doing before. Another problem which has gone is the hate towards all Hutus. During the fifteen years that I lived with the rapist, I had built a kind of hatred in my heart because of his wickedness towards me. The discussions we had in sociotherapy changed me. They taught me to live peacefully with others. I learnt that if people sinned against me, I have to forgive them. This lesson brought peace in my heart. Being angry and bearing this hatred were gradually killing me while they, the sinners, were sleeping. I felt that I have to forgive my enemy, because forgiving brings peace to a broken heart. I did forgive, and I feel better than before because of that. Since I graduated from sociotherapy, I committed myself to do whatever I can in order to live peacefully with others in the future. And then, I have a dream of having a house. After getting a house, I will work and then develop myself further.

Although I am appreciative of sociotherapy, I do not know whether my family's slaughterers are still alive. They were in prison, but they were released after they confessed. They confessed in prison, and later also in Gacaca. That is how we learnt about the death of our mother. They described how they killed my mother when she went to fetch drinking water; they threw stones at her until she died. After they confessed, I did not see them again. I did not testify against the rapist, afraid of being called a mad woman by the public; because although my heart was full of grief and tears, neighbours considered me his wife. Gacaca is almost over by now. Those who looted our properties and those who destroyed our house paid our brother back. But the rapist is still walking around freely.

I would advise other women who have been taken by force by rapists to leave them if they experienced problems similar to mine. I liked that sociotherapy brought me together with other women and that it allowed me to trust myself and others again. Before I joined, I was like a small animal. When someone tried to do anything bad to me, I was reproducing this bad thing twice in return. I have changed now, and I love other 
people. I had forgotten to smile. I am now a changed person who smiles like others and I am looking towards the future.

I encourage all women to join sociotherapy, if they have such an opportunity. If they do not have such a chance, I advise them to search for a friend who can listen to them. 